\title{
Canada-Wheat: discrimination, non-commercial considerations, and the right to regulate through state trading enterprises
}

\author{
BERNARD HOEKMAN \\ Senior Advisor, Research Manager, International Trade Group, Development Research Group, World Bank \\ JOEL P. TRACHTMAN \\ Professor of International Law, Fletcher School of Law and Diplomacy, Tufts University
}

\section{Introduction}

In the Canada-Wheat case, ${ }^{1}$ the WTO Appellate Body delimited the scope of disciplines applicable to state trading enterprises (STEs) under WTO law. The US challenged several Canadian measures. We will focus here on the Canadian Wheat Board (CWB) export regime for wheat. The Canada-Wheat case was brought by the US to address certain practices of the CWB.

Although Canada lost at the Panel stage on certain GATT Article III:4 grounds, Canada mounted a successful defense in connection with claims regarding the CWB's behavior as an STE at the Panel stage: the Panel found that the US had failed to establish that Canada had violated Article XVII:1(a) or (b). ${ }^{2}$ The US appeal addressed the Panel's interpretation of subparagraph (b) of Article XVII:1, and the Panel's application of this interpretation to the CWB export regime. Canada's appeal argued that the Panel inappropriately failed to address the relationship between subparagraph (a) and subparagraph (b) of Article XVII:1, and erroneously assumed that a breach of subparagraph (b) is sufficient to establish a breach of Article XVII:1.

In this case, the Appellate Body adopted an interpretation of Article XVII:1 of GATT that limits its disciplines only to antidiscrimination. The Appellate Body declined to find broader disciplines requiring STEs to operate 'solely in accordance with commercial considerations' as an independent requirement. By doing so, the Appellate Body limited the disciplines applicable to STEs to those that would apply to government regulation of private entities. It declined to find a

1 Appellate Body Report, Canada-Measures Relating to Exports of Wheat and Treatment of Imported Grain, WT/DS276/AB/R, adopted 27 September 2004.

2 Panel Report, Canada - Measures Relating to Exports of Wheat and Treatment of Imported Grain, WT/DS276/R, adopted 27 September 2004, upheld by Appellate Body Report, WT/DS276/AB/R, paras. 6.151 and $7.4(\mathrm{a})$. 
broader requirement that STEs act like private persons, and therefore preserved the possibility that states may use STEs to achieve broader public-policy goals. It found that Article XVII:1 does not impose competition-law-type obligations on STEs.

\section{Background}

STEs commonly take the form of statutory marketing boards. These statutory marketing boards often have exclusive authority to purchase domestic production, to sell for export, and to set purchase and sales prices. They may also capture economies of scale, reducing marketing and other transaction costs for producers (see Secretariat, WTO, 1995).

The statutory objective of the CWB is to market certain grain grown in Canada in an 'orderly manner' in interprovincial and export trade. The CWB is granted exclusive authority over the sale in export markets and for human consumption in the domestic market of wheat and barley grown in a 'designated area'. The 'designated area' includes the Canadian provinces of Manitoba, Saskatchewan, Alberta, and the Peace River area of the province of British Columbia. ${ }^{3}$ Thus, the CWB is a monopolist for sales on the domestic and export markets, and a monopsonist for Canadian producers of wheat and barley that operate in the designated area. Exclusive control over both export and domestic sales makes the CWB a so-called 'single desk' STE.

The US asserted, inter alia, that the CWB export regime was inconsistent with Canada's obligations under Article XVII:1 of GATT 1994. The US argued that the following three elements, in combination, violated Article XVII:1: (a) the legal framework of the CWB, (b) Canada's provision to the CWB of exclusive and special privileges, and (c) the actions of Canada and the CWB with respect to the CWB's purchases and sales involving wheat exports. ${ }^{4}$ That is, these three measures 'collectively' constituted the measure challenged: the 'CWB Export Regime'.

More particularly, the exclusive and special privileges at issue (referred to in item (b) above) were the following:

(i) the exclusive right to purchase and sell Western Canadian wheat for export and domestic human consumption;

(ii) the right to set, subject to government approval, the initial price payable for Western Canadian wheat destined for export or domestic human consumption;

(iii) the government guarantee of the initial payment to producers of Western Canadian wheat;

3 Canadian Notification to the Working Party on State Trading Enterprises of the WTO, G/STR/N/4/ CAN.

4 Panel Report, para. 6.12. 
(iv) the government guarantee of the CWB's borrowing; and

(v) government guarantees of certain CWB credit sales to foreign buyers. ${ }^{5}$

The US argued that the CWB Export Regime led the CWB to violate Article XVII:1(a) and (b) of GATT. The US challenged the CWB Export Regime as a whole, rather than any individual element. ${ }^{6}$ This was understood by the Panel as a 'per se' challenge to the CWB Export Regime, rather than a challenge to a particular action. ${ }^{7}$

The US claim rested on four broad assertions. First, the privileges enjoyed by the CWB gave it more flexibility with respect to pricing and other sales terms than a commercial actor. This included the ability to pay wheat producers prices below the market price. Second, this flexibility allowed the CWB to offer non-commercial sales terms, denying commercial firms an opportunity to compete. Third, the structure of the CWB induced it to maximize sales, or revenues, rather than profits. Fourth, the Canadian government did not take steps to cause the CWB to comply with Article XVII: $1 .^{8}$

The substance of the US claim was that 'the CWB statute does not require the CWB to sell its wheat for export in accordance with commercial considerations, and the CWB maintains the secrecy of its transaction-specific sales practices. Moreover ... the exclusive and special privileges enjoyed by the CWB detach the CWB from the economic considerations that would govern the conduct of commercial actors engaged in the purchase and sale of wheat. ${ }^{\text {'9 }}$ Thus, the main concern of the US was structural: the issue was a perception that the CWB is structured in a way that ensures that it will not act, or at least does not ensure that it will act, 'solely in accordance with commercial considerations'.

The WTO proceeding discussed in this paper is only a part of a larger conflict between Canada and the US over wheat. In a series of domestic investigations, US authorities determined that Canadian wheat was being subsidized and dumped in the US, and was therefore subject to countervailing duties and anti-dumping duties. However, certain of these determinations were appealed to a NAFTA Chapter 19 Panel, which overturned the findings. ${ }^{10}$ Thus, the attack under Article XVII might have been viewed as a less attractive alternative compared to these other previously frustrated routes of attack.

5 Panel Report, para. 6.15. See Alberta Agriculture, Food and Rural Development,Canadian Wheat Board Government Guarantees for a description of the three guarantees. Available at http://www.choice matters.gov.ab.ca.

6 Panel Report, para. 6.26.

7 Panel Report, para. 6.28.

8 Panel Report, paras. 6.110-6.114.

9 First Written Submission of the United States of America, Canada-Measures Relating to Exports of Wheat and Treatment of Imported Grain, WT/DS276, 1 August 2003, para. 20.

10 NAFTA Article 1904 Panel Review, In the Matter of Hard Red Spring Wheat from Canada, No. USA-CDA-2003-1904-06 (7 June 2005; 12 December 2005). 


\section{State trading enterprises and WTO rules}

STEs are used by governments as instruments of regulation. They may be used to achieve a variety of public-policy goals in industrial policy, including in relation to the control of imports and exports. As tools of state intervention in the market, STEs may distort competition, and may be inconsistent with liberalization. But, of course, this alone does not make them inconsistent with WTO law or policy.

However, it is possible that STEs may be used to circumvent certain WTO commitments with respect to market access and subsidies. ${ }^{11}$ They might do so in a number of ways. First, they could circumvent the MFN principle of GATT Article I by discriminating among trading partners in their decisions regarding purchase and sale. Second, they could circumvent the national-treatment principle of GATT Article III by discriminating between domestic and imported goods in their decisions regarding purchases. Third, if they hold exclusive import privileges, they could effectively restrict quantities of imports, inconsistently with the principles of Article XI of GATT. Fourth, they might exercise exclusive import rights to sell domestically at mark-ups that operate similarly to tariffs, but that exceed bound tariffs. Fifth, STEs may use their purchases and sales to subsidize sellers or buyers (Hoekman and Low, 1998). Much of the possibility for circumvention of WTO commitments is based on the possibility that STE decision making may be opaque, rendering it difficult to determine whether they discriminate or confer subsidies (Hoekman and Low, 1998; see also Petersmann, 1998). It is often difficult to evaluate whether their prices are subsidized (see Horlick and Mowry, 1998).

During the GATT period, prior to 1995, STEs did not play a major role in trade negotiations, largely because the main sectors and countries in which STEs are active - agriculture, services, and centrally planned economies - were effectively excluded from GATT disciplines (Hoekman and Low, 1998). STEs declined in importance with the growth of the Washington Consensus, and related moves toward reduced state intervention in the economy. In agriculture, for example, the New Zealand Dairy Board and the Australian Wheat Board have been transformed into grower cooperatives that do not receive government support (Young, 2005), while many of the marketing boards that were used by developing-country governments to set producer prices and control exports have been dismantled.

The Uruguay Round did not produce additional substantive regulation of STEs. The US has advocated additional disciplines on STEs, including prohibitions on monopoly rights of STEs (USDA, 2002). Specifically, the US proposed the following disciplines:

1. Members shall not restrict the right of any interested entity to export, or to purchase for export, agricultural products.

11 The Appellate Body has termed Article XVII:1(a) an 'anti-circumvention' provision. Appellate Body Report, para. 85 . 
2. No special financing privileges, including government grants, loans, loan guarantees, or underwriting of operational costs, shall be granted to state trading enterprises that export for sale, directly or indirectly, a significant share of the respective Member's total exports of an agricultural product.

3. Any Member that establishes, or maintains, for agricultural products, an export state trading enterprise shall give notice in writing, at least annually, to the Committee on Agriculture, of relevant information, including: initial and subsequent acquisition costs incurred and export prices of products exported or sold for export by such enterprises on a transaction-specific basis. Any Member may request the Member maintaining an export state trading enterprise for agriculture to provide specific information concerning all operations relevant to the export of agricultural products, as described above.

The US's greatest concern has been the CWB, which competes with US firms in world wheat markets, as well as in the US (Abbott and Young, 2003). However, with the entry of China into the WTO, and the expected entry of Russia, there is clearly a more general interest to ensure that STEs are not used to undercut market access and subsidization commitments.

\section{Economic dimensions}

The conflict that gave rise to the present case essentially revolves around competition for third markets, as both countries are major producers of wheat and large net exporters. Whereas Canada uses the CWB as the conduit for its exports of wheat, the US relies on a small number of large private firms to market wheat on export markets. Prior to the Uruguay Round (1995), US producers could benefit from export subsidies - through the US Export Enhancement Program. One result of the Uruguay Round was to impose disciplines on export-subsidy policies. A corollary was that US and other producers in countries that had benefited from export subsidies perceived an 'unfair' asymmetry to have emerged: they had become subject to disciplines, whereas countries with state trading agencies might be able to continue to price discriminate across markets and effectively subsidize exports.

From an economic perspective the relevant questions are whether (i) STEs such as the CWB do indeed engage in price discrimination on export markets; and (ii) this is a reflection of de facto export subsidization made possible by the way the CWB is structured and operates. ${ }^{12}$

12 That is, the observed discrimination would not also be pursued by a profit-maximizing private firm. Note that the focus in this paper is on exporting STEs, not importing STEs. In practice, STEs in net importers may circumvent negotiated market-access commitments through their behavior. This became more important post-Uruguay Round due to the shift to tariffication of agricultural protection and the use of tariff-rate quotas (TRQs) to guarantee minimum access to highly protected markets. These TRQs require management (allocation mechanisms), something that may be done by STEs. Article XVII arguably is primarily focused on this type of issue: a complement to other GATT articles that aim to preclude use of alternative instruments to restrict access more than what has been negotiated through tariff bindings. While the US did contest import-related issues, it did not appeal any of the Panel findings in this area. 
A legal issue that arises insofar as the CWB can be argued to engage in subsidization of exports is to what extent such behavior is (can be) disciplined through other WTO provisions, e.g. the Agreement on Agriculture disciplines. Article XVII WTO does not deal with de jure subsidization - this is (must be) addressed through export-subsidy disciplines. However, if STE behavior results in de facto subsidization because of discriminatory pricing behavior and exploitation of market power, Article XVII may be violated. While other WTO provisions apply, and might be violated by the same behavior, Article XVII may provide a more effective means by which to discipline this behavior. Furthermore, to the extent that the economic 'subsidization' would not qualify as legal 'subsidization' because it involves a benefit being required to be provided by private Canadian producers to the CWB, rather than a benefit being provided by government, no WTO subsidies disciplines would apply.

Thus, the reason for the US concern with the structure of the CWB in this case seems to have been the risk of implicit subsidization in the economic sense if not in the WTO legal sense. Single-desk status potentially gives the CWB the economic power to price discriminate or to cross-subsidize between domestic and foreign markets. However, such price discrimination may reflect market factors (demand conditions in different markets) and differences in product composition (quality) as well as the monopolist-cum-monopsonist status of the CWB.

The CWB engages in a number of practices that may allow it to reduce prices on export markets below what competitors can charge in the absence of export subsidies. One of these is a two-part payment system under which farmers obtain only partial payment for their crops when delivered to the CWB. This first payment is determined by a minimum price for farmers, guaranteed by the government. It is supplemented by a final payment once output has been sold on export markets, and selling expenses, overheads, etc. have been netted out. The CWB also engages in price pooling: domestic producers are paid the average price (net of costs) obtained for a specific quality/variety of wheat and barley on the domestic and all export markets.

The combination of price pooling and two-part payment scheme may result in the CWB being able to price below competitors by credibly lowering the costs of the output that is exported (i.e., low initial payments could be used as a credible precommitment device in an export-competition game) and/or through crosssubsidization by 'pricing to market' - insofar as this entails losses on some export markets, this can be compensated by higher prices on other markets. The two-part pricing scheme may in effect imply that the CWB is being given a short-term 'loan' by Canadian farmers, as they must accept the minimum, initial, average price offered by the CWB. In addition, the CWB benefits from government guarantees of both its debt and certain credits it may grant its foreign buyers. ${ }^{13}$

13 In principle, government loan guarantees and credits that are conditional on exports would be covered by the Agreement on Agriculture and the SCM Agreement. 
As a result of its exclusivity rights, the CWB can engage in a variety of strategies. Which strategy it will pursue will depend on the underlying objectives it has been assigned. As a government entity, the objective of the CWB is not necessarily profit maximization. Indeed, a rationale for the creation and operation of STEs generally includes equity as well as efficiency objectives. In the field of agriculture, STEs can serve important public-policy purposes, such as price support or stabilization, internalization of externalities (quality and associated reputational benefits for the country as a whole), and income redistribution. Thus, in addition to exploitation of national-market power by aggregating the supplies of many small farmers (economies of scale, etc.), STEs often act to redistribute income towards - or, more frequently, away from - farmers. The latter objective has often been important in developing countries, where governments seek to use low producer prices as a means of transferring resources to consumers of food in urban areas or to support investments elsewhere in the economy.

Knowing what the underlying national objectives are is clearly important from the perspective of national welfare and the evaluation/design of policy. However, what the objectives are is not always relevant from a WTO perspective, as its focus may be only on the question whether the trade impacts of a policy result in discrimination that goes beyond what a country may impose given its commitments in the WTO. As a result, WTO rules in this area, as in others, may result in incentives for countries to use less efficient instruments to pursue a given objective. In the case of STEs, for example, if the underlying objective is to raise exports, explicit export subsidies may be the more efficient (and transparent) instrument. For example, simple economic theory suggests that for a given target increase in domestic production, the use of export subsidies will generate lower welfare costs for the imposing country than an STE that uses price pooling as a way of raising average prices for farmers (see Alston and Gray, 2000). ${ }^{14}$

Canada is a major wheat exporter. Thus, it has some market power on the world market. In this connection, it is important to recognize that Canadian wheat is a differentiated product. For a given type of wheat, it is of more uniform and of higher average quality than US wheat. In part, this is because of the operation of the CWB, which sets minimum standards and specifies the type of seeds that may be used for a given quality/type of wheat or barley that is to be procured and exported.

The empirical literature on the global wheat market suggests that this may be best characterized as a quantity-setting oligopoly. In the case of barley, price

14 Important questions for domestic policy and assessing the costs and benefits of alternative instruments are the size of the excess burden of taxation needed to finance export subsidies and administrative costs (transfer efficiency), the incidence of the 'tax' that is used to generate a given transfer to farmers - taxpayers in the case of export subsidies, consumers in the case of STEs - whether the STE is being used as a mechanism to ensure that a greater share of profits accrue to farmers instead of middlemen/ traders (the concentration ratio of wholesalers/distributors in the US is over $75 \%$ for example), etc. In this paper, we abstract from these types of domestic-policy questions. 
setting does not appear to be supported by the data - STEs and other suppliers do not have market leadership and can be characterized as engaging in Cournot competition. In the case of wheat, the CWB does engage in price discrimination, but the evidence suggests much, if not most, of this is due to the fact that there are significant quality differences among types of wheat exported to different markets. ${ }^{15}$ Moreover, research suggests that the CWB does not set initial prices to farmers optimally from a profit maximization/rent shifting perspective. Prices paid to farmers are 'too high': producers receive a higher average price than they should if the CWB was seeking to maximize profits. This suggests either that strategic motivations do not drive pricing decisions, that regulation and other oversight of the CWB ensure that interests of farmers dominate, or that because of the nature of the differentiated products it makes more sense to focus on measures to improve quality and exploit quality differences (Lavoie, 2005 and Dong, Marsh, and Stiegert, 2006). ${ }^{16}$ In practice, it appears that the CWB obtains a premium price for many of its exports, rather than selling output at 'subsidized' levels, reflecting the higher quality/differentiated nature of its exports (Lavoie, 2005 and Sumner and Boltuck, 2001).

As discussed further below, what matters from the perspective of the WTO (Article XVII) is whether any observed price discrimination across foreign markets or between domestic and foreign markets would also be pursued by a private firm (such as a cooperative of farmers). Independent of the specific features of the CWB - such as price pooling - the evidence of extensive product differentiation in the wheat market suggests that private firms would also pursue pricediscrimination strategies in markets where they have (some) pricing power. That, in turn, suggests that in practice it is difficult to establish a private 'commercial' counter-factual situation where discrimination would not be optimal.

\section{Analyzing the disciplines of Article XVII}

Article XVII:1 of GATT applies to STEs. Article XVII:1 provides as follows:

1.*17 (a) Each contracting party undertakes that if it establishes or maintains a State enterprise, wherever located, or grants to any enterprise, formally or in

15 See Lavoie, 2005, and Dong, Marsh, and Stiegert, 2006, for recent empirical analyses of the operation of the CWB in wheat and barley markets, respectively. These papers also contain extensive references to the economic literature on STEs in general and the CWB in particular.

16 Note that insofar as average total prices paid to Canadian producers are not suppressed so as to maximize the profits of the CWB, this may have the effect of increasing total output, enhancing competition on world markets. The same outcome may result from price pooling (paying farmers the average price obtained across all markets).

17 Asterisks refer to 'ad notes' that form part of the GATT. For example, and as relevant to this case, the ad note to Article XVII:1 provides, inter alia, that 'The charging by a state enterprise of different prices for its sales of a product in different markets is not precluded by the provisions of this Article, provided that such different prices are charged for commercial reasons, to meet conditions of supply and demand in export markets.' 
effect, exclusive or special privileges, ${ }^{*}$ such enterprise shall, in its purchases or sales involving either imports or exports, act in a manner consistent with the general principles of non-discriminatory treatment prescribed in this Agreement for governmental measures affecting imports or exports by private traders.

(b) The provisions of subparagraph $(a)$ of this paragraph shall be understood to require that such enterprises shall, having due regard to the other provisions of this Agreement, make any such purchases or sales solely in accordance with commercial considerations, ${ }^{*}$ including price, quality, availability, marketability, transportation and other conditions of purchase or sale, and shall afford the enterprises of the other contracting parties adequate opportunity, in accordance with customary business practice, to compete for participation in such purchases or sales.

\subsection{Scope of application of Article XVII:1}

GATT does not define STEs. The Uruguay Round Understanding on the Interpretation of Article XVII of the General Agreement on Tariffs and Trade (the 'Understanding') provides a working definition for STEs, to be used to determine the scope of the obligation of notification specified in the Understanding:

Governmental and non-governmental enterprises, including marketing boards, which have been granted exclusive or special rights or privileges, including statutory or constitutional powers, in the exercise of which they influence through their purchases or sales the level or direction of imports or exports.

Importantly, the essence of this definition is, first, that there are exclusive or special privileges, and, second, that in the exercise of these powers, the STE influences through purchases or sales the level or direction of imports or exports.

However, the definition contained in the Understanding is narrower than the scope of application of Article XVII:1. The Appellate Body cited the Panel's statement that "Like the parties, the Panel uses the term "STE" or "state trading enterprise" to refer to both types of enterprises covered by Article XVII:1, i.e., State enterprises or enterprises that have formally or in effect been granted exclusive or special privileges.' 18

In the present case, there was no dispute as to whether the CWB is an STE, as Canada had notified the CWB as an STE. ${ }^{19}$

\subsection{Discrimination and commercial considerations}

In the Canada-Wheat case, Canada argued that the Panel erred 'in not considering the "proper" relationship between subparagraphs (a) and (b) of Article XVII:1 of the GATT 1994 and in proceeding to examine the consistency of the CWB Export

18 Appellate Body Report, para. 114, citing Panel Report, para. 6.33.

19 Panel Report, para. 6.108. See Working Party on State Trading Enterprises, New and Full Notification [by Canada] Pursuant to Article XVII:4(A) of the GATT and Paragraph 1 of the Understanding on the Interpretation of Article XVII, G/STR/N/4/CAN, 5 November 2002. 
Regime with Article XVII:1(b) without first having found a breach of Article XVII:1(a). ${ }^{, 20}$ According to Canada, because the Panel made this error, it also erred by failing to make a finding of discriminatory conduct under subparagraph (a) before examining the 'commerciality' of the CWB Export Regime under subparagraph (b).

The United States's appeal related to 'the Panel's interpretation of subparagraph (b) of Article XVII:1; to the Panel's application of this interpretation to the CWB Export Regime; and to the Panel's ultimate finding that the United States had not established any inconsistency with the principles of subparagraphs (a) or (b) of Article XVII:1 of the GATT 1994. ${ }^{21}$ The US sought a finding of broad disciplines on the behavior of STEs, including their competitive behavior. The US argued that Article XVII:1(b) establishes an independent obligation for STEs to base their decisions on commercial considerations. The US argued that subparagraphs (a) and (b) contain 'multiple, distinct obligations'. ${ }^{22}$

The Appellate Body began its consideration of Article XVII:1 by examining the relationship between subparagraphs (a) and (b): between references to a finding of discrimination and a finding of failure to purchase and sell 'solely in accordance with commercial considerations'.

The US argued that its position was supported by statements of the Panel in Korea-Various Measures on Beef, suggesting that the obligations expressed in subparagraphs (a) and (b) are independent:

A conclusion that the principle of non-discrimination was violated would suffice to prove a violation of Article XVII; similarly, a conclusion that a decision to purchase or buy was not based on 'commercial considerations', would also suffice to show a violation of Article XVII. ${ }^{23}$

Canada, on the other hand, argued that the above statement by the Panel in the Korea-Various Measures on Beef case was not necessary to the Panel's decision. Moreover, the Panel in Korea-Various Measures on Beef expressly endorsed the views of the Panel in Canada-FIRA, which read subparagraphs (a) and (b) as one obligation. ${ }^{24}$ The Panel in Canada-FIRA stated that ' $[\mathrm{t}]$ he fact that sub-paragraph (b) does not establish a separate general obligation to allow enterprises to act in accordance with commercial considerations, but merely defines the obligations set out in the preceding sub-paragraph, is made clear through the introductory words. ${ }^{25}$

20 Appellate Body Report, para. 76.

21 Appellate Body Report, para. 77 (emphasis in original) (citation omitted).

22 U.S. Appellee's Submission, para. 5.

23 Korea-Measures Affecting Imports of Fresh, Chilled and Frozen Beef, WT/DS161,169/R, 31 July 2000 , para. 757.

24 Panel Report, para. 6.56.

25 Report of the Panel, Canada-Administration of the Foreign Investment Review Act, adopted 7 February 1984, para. 5.16, L/5504, 30S/140. 
In accord with the Panel in Canada-FIRA, the Panel in Korea-Various Measures on Beef stated that the scope of paragraph (b) defines the obligations in paragraph (a): evidence as to whether the STE action is based on commercial considerations is to be used to assess discrimination. ${ }^{26}$ This would seem to confirm the Canadian argument, and the Appellate Body found that it was 'not clear that the panel in Korea-Various Measures on Beef intended [the language quoted above] to have the meaning the United States seeks to ascribe to it'. ${ }^{27}$ Indeed, there is much language in the Korea-Various Measures on Beef decision to support the Canadian position.

The Appellate Body found that the 'shall be understood' language in subparagraph (b), referring to subparagraph (a), means that subparagraph (b) is dependent upon, and an explanation of, subparagraph (a). ${ }^{28}$ Here the Appellate Body followed the reasoning of the Panel in the Canada-FIRA case. ${ }^{29}$ Subparagraph (b) clarifies the general obligation of nondiscrimination provided in subparagraph (a). Subparagraph (b) does not establish requirements independent of subparagraph (a). ${ }^{30}$

Therefore, in future cases under Article XVII:1, a Panel will need to begin its analysis with an evaluation of the application of subparagraph (a). 'It appears to us that these [the subparagraph (b)] types of differential treatment would be the most likely to occur in practice and, therefore, that most if not all cases under Article XVII:1 will involve an analysis of both subparagraphs (a) and (b)., ${ }^{, 31}$ Canada argued that a Panel must first find discrimination under subparagraph (a) before it can go on to make findings under subparagraph (b), and that subparagraph (b) does not create independent obligations. ${ }^{32}$ Rather, '[i]n Canada's view, what subparagraph (b) does is to interpret and temper the obligation under subparagraph (a)'.33

While the Appellate Body did not find that a full analysis under subparagraph (a) is required before proceeding to subparagraph (b), it found that a Panel must at least identify the differential treatment alleged to be discriminatory under subparagraph (a) before performing its analysis under subparagraph (b). ${ }^{34}$ The Appellate Body found that an evaluation of whether discrimination is based on commercial considerations within the meaning of subparagraph (b) might depend on the type of discrimination identified under subparagraph (a). ${ }^{35}$ The Appellate

26 Panel Report on Korea - Various Measures on Beef, para. 755.

27 Appellate Body Report, para. 103.

28 Appellate Body Report, paras. 89-91; 100.

29 Canada-Administration of the Foreign Investment Review Act, L504, adopted 7 February 1984, $30 S / 140$.

30 Appellate Body Report, para. 100.

31 Appellate Body Report, para. 99.

32 Panel Report, para. 6.54.

33 Ibid.

34 Appellate Body Report, paras. 111-112.

35 Appellate Body Report, para. 110. 
Body stated that '[s]ubparagraph (b) sets forth two specific conditions with which an STE must comply if allegedly discriminatory conduct falling, prima facie, within the scope of subparagraph (a) is to be found consistent with Article XVII:1'. ${ }^{36}$ Thus, as suggested by Canada, subparagraph (b) can serve to 'temper' or limit the scope of subparagraph (a): not all discrimination within the meaning of subparagraph (a) violates Article XVII:1.

The Panel in Korea-Various Measures on Beef had said that the variables in subparagraph (b) are to be used to assess whether the national measure is discriminatory. ${ }^{37}$ The Appellate Body in the present case stated that it did not decide whether a Panel may find a violation of subparagraph (a) alone, without considering subparagraph (b). ${ }^{38}$

The Panel had reserved on its analysis of subparagraph (a), subject to its determination under subparagraph (b). Under these circumstances, the Appellate Body found that the Panel's inquiry under subparagraph (b) was made in the context of an inquiry into alleged discriminatory practices, and therefore the Panel did not misapply these two provisions by focusing its analysis on subparagraph (b). ${ }^{39}$ That is, given that the Panel found no non-commercial sales within the meaning of subparagraph (b), and the US did not establish an independent claim of discrimination under subparagraph (a), there was no error.

The logic advanced by the Appellate Body is not ineluctable. The 'shall be understood' language could equally be understood to deem failure to 'make purchases or sales solely in accordance with commercial considerations' to constitute 'discrimination' under subparagraph (a), reversing the order of analysis. The US alleged pursuant to Article XVII:1 that Canada engaged in discrimination by virtue of its alleged non-commercial sales. ${ }^{40}$ Indeed, the US argued that 'on the facts of this case, the alleged discriminatory sales behaviour by the CWB is a necessary result of the CWB not making sales solely in accordance with commercial considerations'. ${ }^{41}$

Furthermore, all discrimination in the sense of subparagraph (a) (in the WTO sense) would be expected to involve decisions based on non-commercial considerations. Discrimination in the WTO sense involves government (policy) measures that distinguish between goods in a way that a private person, absent the policy, would not. Discrimination in this context is the use of impermissible considerations in choosing suppliers or customers $:^{42}$ commercial considerations are always permissible under WTO law. Moreover, in practice it will frequently be difficult, if not impossible, to objectively determine whether or not a specific

36 Ibid.

37 Korea-Various Measures on Beef, para. 757.

38 Appellate Body Report, at para. 106, note 115.

39 Appellate Body Report, paras. 119-123.

40 Appellate Body Report, para. 118.

41 Panel Report, para. 6.58.

42 See Panel Report, para. 6.88. 
transaction is based on commercial considerations, as pricing and allocation decisions tend to be multidimensional and may reflect factors/strategies that are not known or observable to outsiders.

Thus, it seems logically impossible for subparagraph (b) to narrow the scope of subparagraph (a). Although the Appellate Body suggests that measures that comply with the two prongs of subparagraph (b) - commercial considerations and opportunities to enterprises of other WTO members - might escape the disciplines of subparagraph (a), ${ }^{43}$ this understanding seems to lack textual support, and it is difficult to see how it would apply.

\subsection{Commercial considerations}

The US argued that ' $[\mathrm{w}]$ here an export STE has been granted special and exclusive privileges which permit it to operate without the normal market constraints faced by a commercial actor, that STE could make use of its privileges to gain market share in particular markets, but such behaviour would not be commercial' ${ }^{44}$ Under this reading, the prohibition of non-commercial considerations could have a scope that goes beyond discrimination: it would not necessarily be discriminatory to seek to maximize market share, but it would, according to the US, be 'noncommercial'. However, there seems little reason to believe that a requirement of commercial considerations excludes a goal of increasing market share. ${ }^{45}$

The Appellate Body confirmed the Panel's understanding of the term 'commercial considerations':

The Panel began its analysis by considering the meaning of the term 'commercial considerations' in subparagraph (b) and found that this term should be understood as meaning 'considerations pertaining to commerce and trade, or considerations which involve regarding purchases or sales 'as mere matters of business'.' The Panel also determined that the requirement that STEs act solely in accordance with such considerations 'must imply that they should seek to purchase or sell on terms which are economically advantageous for themselves and/or their owners, members, beneficiaries, etc.' Thus, the Panel interpreted the term 'commercial considerations' as encompassing a range of different considerations that are defined in any given case by the type of 'business' involved (purchases or sales), and by the economic considerations that motivate actors engaged in business in the relevant market(s). ${ }^{46}$

Thus, there is no a priori reason to exclude concerns for market share, as opposed to profits.

43 Appellate Body Report, para. 110.

44 Panel Report, para. 6.74.

45 The types of actions taken to gain market share would be likely to involve price discrimination among export markets. However, the ad note to Article XVII stipulates that price discrimination is permitted, so long as it is motivated by commercial considerations.

46 Appellate Body Report, para. 140, 144 (citations omitted). 
The Appellate Body's understanding of the relationship between subparagraphs (a) and (b) informed its interpretation of subparagraph (b). Subparagraph (b) does not address all failures to act in a commercial manner, but only those related to discrimination. The Appellate Body pointed out that 'Article XVII:1 imposes an obligation on Members not to use STEs in order to discriminate in ways that would be prohibited if undertaken directly by Members' ${ }^{47}$

\subsection{Competition and STE behavior}

The central question addressed in this case by the Appellate Body was whether the nondiscriminatory-treatment prong of (a) is independent of the commercial considerations prong of subparagraph (b). The US argued that these were independent, several obligations, either of which could be the basis for a successful attack. The Appellate Body concluded that subparagraph (b) clarifies the scope of the non-discrimination obligation in subparagraph (a). According to the Appellate Body, the types of discrimination listed in subparagraph (b) are the most likely, but do not exhaust the category of measures that might violate subparagraph (a). ${ }^{48}$ Therefore, Panels must begin by analyzing subparagraph (a), and will usually, but not always, also have to evaluate subparagraph (b). ${ }^{49}$

The Appellate Body stated that '[t]he disciplines of Article XVII:1 are aimed at preventing certain types of discriminatory behaviour. We see no basis for interpreting that provision as imposing comprehensive competition-law-type obligations on STEs, as the United States would have us do. ${ }^{50}$ Thus, subparagraph (b) does not establish separate requirements independent of subparagraph (a). ${ }^{\mathbf{5 1}}$ The Appellate Body quoted approvingly the Canada-FIRA Panel report to the effect that subparagraph (b) does not establish a separate obligation to act in accordance with commercial considerations. ${ }^{52}$

Importantly, Article XVII is therefore not a broad-ranging requirement that STEs emulate private-sector behavior. Rather, STEs may engage in actions that are not commercially motivated - that reflect public-policy objectives - so long as the implementation of that public policy is not discriminatory. In other words, STEs may act as agents of public policy, so long as they comply with the nondiscrimination requirements of Article XVII. The Panel articulated this concept: 'Finally, the United States' argument that STEs must act like "commercial actors" tends to overlook the fact that STEs are not necessarily used only for commercial purposes. STEs may also be established or maintained to carry out governmental

47 Appellate Body Report, para. 98.

48 Appellate Body Report, para. 99.

49 Appellate Body Report, para. 109.

50 Appellate Body Report, para. 145.

51 Appellate Body Report, para. 100.

52 Appellate Body Report, para. 104. See Canada - Administration of the Foreign Investment Review Act, L504, adopted 7 February 1984, 30S/140, para. 5.16. 
policies or programmes (e.g., policies related to food security, policies aimed at reducing alcohol consumption, policies to achieve price stabilization, etc.). ${ }^{{ }^{53}}$

The US also argued that the second clause of subparagraph (b) of Article XVII: 1 - requiring STEs to 'afford the enterprises of other Members adequate opportunity ... to compete for participation in such purchases or sales' - requires that adequate opportunities be afforded to enterprises that wished to sell in competition with the STE. ${ }^{54}$ However, the Appellate Body found that the term 'such purchases or sales' refers back to subparagraph (a), which addresses purchases and sales by the STE, not by competing enterprises. Thus, the requisite adequate opportunity is to be a purchaser or seller counterpart to the STE, not to be a competitor to the STE. ${ }^{\mathbf{5 5}}$

The Appellate Body's understanding has important substantive ramifications. There is no independent obligation of decisionmaking in accordance with commercial considerations. Subparagraph (b) is neither a source of independent obligations, nor a basis for finding a deemed violation of subparagraph (a). Paragraph 145 of the Appellate Body report is worth quoting in full:

At the same time, our interpretation of the relationship between subparagraphs (a) and (b) of Article XVII:1 necessarily implies that the scope of the inquiry to be undertaken under subparagraph (b) must be governed by the principles of subparagraph (a). In other words, a panel inquiring whether an STE has acted solely in accordance with commercial considerations must undertake this inquiry with respect to the market(s) in which the STE is alleged to be engaging in discriminatory conduct. Subparagraph (b) does not give panels a mandate to engage in a broader inquiry into whether, in the abstract, STEs are acting 'commercially'. The disciplines of Article XVII:1 are aimed at preventing certain types of discriminatory behaviour. We see no basis for interpreting that provision as imposing comprehensive competition-law-type obligations on STEs, as the United States would have us do. (citation omitted)

The US argument in this case can be linked to the broader argument regarding the role of competition policy in international trade. In a sense, a single-desk STE is similar to a private domestic monopolist (see McCorriston and MacLaren, 2002). A private domestic monopolist would have the power to price discriminate and to cross-subsidize, but would lack the interest that a STE might have in providing a net subsidy. So, assuming for a moment that the extent of STE net subsidization could be identified and addressed through WTO subsidies law, the other concerns are similar.

In the debate regarding competition policy at the WTO, proponents argue that states have incentives to externalize anticompetitive effects on one another through lax enforcement of competition law when the adverse effects occur abroad (see

53 Panel Report, para. 6.96 (citation omitted).

54 Appellate Body Report, para. 152.

55 Appellate Body Report, para. 157. 
Guzman, 2001 and 2004). The STE context is more direct. States are not simply failing to have or enforce competition law; they are directly establishing monopolies. Indeed, Sir Leon Brittan has opined as follows:

I should at this point raise a related issue concerning state trading, in other words, where a government has a special right to a designated corporation to import or export or to distribute certain goods ... I think that, if we are to look at international competition rules seriously, the time is ripe to consider whether this antiquated form of monopoly trading can be phased out altogether (1997).

That said, there is an important difference between the domain of competition policy, especially if defined in US terms as antitrust law and enforcement, and STEs. The latter are mandated by governments, as are any other entities with exclusive rights and privileges. In practice, competition law often does not apply to the domestic actions of government-supported or mandated entities because their actions reflect government policy. The implication is that this is a debate that must extend to what falls under Article 86 of the EC Treaty (formerly Article 90 of the Treaty of Rome): exclusive rights and State monopolies. Finally, it is worth noting that certain types of government policies - including STEs - may be appropriate responses to the exercise of market power by large multinational corporations in particular fields. 'The assumption of a competitive alternative inevitably leads to the conclusion that elimination of STEs would lead to improved market performance' (see Paddock, 1998). In addition to questions regarding the assumption of perfect competition, it should also be borne in mind that STEs may maximize total producer surplus rather than profits (McCorriston and MacLaren, 2002).

\subsection{Article XVII and Article III}

There has been some dispute as to whether Article XVII:1 includes a prohibition of discrimination in the national-treatment sense (the Article III sense), in addition to a prohibition of discrimination in the MFN sense (Petersmann, 1998). The Panel in Canada-FIRA suggested in dictum that it did not. ${ }^{56}$ In the Korea-Various Measures on Beef decision, the Panel held that the principles referenced in Article XVII:1(a) include at least the provisions of Articles I and III of GATT. ${ }^{57}$ In the instant case, the Panel did not consider what types of discrimination are covered by

56 It 'saw great force in Canada's argument that only the most-favoured-nation and not the national treatment obligations fall within the scope of the general principles referred to in Article XVII:1(a)'. Canada - Administration of the Foreign Investment Review Act, adopted 7 February 1984, BISD 30S/140, 163, para. 5.16.

57 Panel Report on Korea-Various Measures on Beef, para. 753, citing Panel Report on Canada - Import, Distribution and Sale of Alcoholic Drinks by Canadian Provincial Marketing Agencies, adopted 18 February 1992, BISD 39S/27 (EC), para. 4.26; Panel Report on Canada-Import, Distribution and Sale of Alcoholic Drinks by Canadian Provincial Marketing Agencies, adopted 18 February 1992, BISD 39S/27 (US), para. 5.15, stating that 'This interpretation was confirmed a contrario by the wording of Article III: 8(a).' 
the reference to 'principles of non-discriminatory treatment' in Article XVII:1(a). Nor was the Appellate Body requested to address this issue. ${ }^{58}$

There are different views regarding whether Article III itself is separately applicable to STEs (see Davey, 1998). If Article III applies to STE behavior, is every violation of the antidiscrimination requirement of Article XVII:1 also a violation of Article III? It appears not. Article III:4 speaks of 'laws, regulations or requirements affecting ... internal sale, offering for sale, purchase, transportation, distribution or use.' So there may be a loophole for purchase or sale decisions, although it may be possible to read this language broadly enough to include STE purchasing requirements.

On the other hand, Article III:8(a) excludes from coverage government procurement for its own use, and by a contrario reasoning seems to leave included in other provisions of Article III government procurement and resale for commercial use.$^{59}$ But this argument must encounter an expressio unius argument based on the Ad Note to Articles XI, XII, XIII, XIV, and XVIII, which specifically states that these Articles include restrictions made effective through STEs. ${ }^{60}$ Its failure to include Article III supports an argument that Article III does not cover acts of STEs. However, in Canada - Import, Distribution and Sale of Alcoholic Drinks by Canadian Provincial Marketing Agencies, the 1992 Panel found certain STE practices to violate Article III. ${ }^{61}$

Furthermore, there may be a question as to whether STE purchase or sale decisions are 'measures' of the relevant member state. Is the STE an organ of the relevant member state for purposes of responsibility under WTO law, or an independent legal entity? This is an issue of the scope of state responsibility for STEs. In the context of Article XVII, the Panel in the instant case stated that 'under Article XVII:1(a), non-conforming conduct by a Member's STE engages that Member's responsibility under international law, even in the absence of intervention of the Member itself, as would be necessary under Article XVII:1(c). ${ }^{\text {'62 }}$ But does a violation of Article III by a STE violate the member state's obligations thereunder? Perhaps it is best to say that if Article III governs STE behavior, then the member state has an obligation to ensure compliance. This would appear to be the result under Article XVI:4 of the WTO Charter.

On the other hand, there is some question whether the disciplines of Article XVII are subsumed by other provisions of GATT, including Article III. 'It is

58 Appellate Body Report, para. 88.

59 Canada-Import, Distribution and Sale of Alcoholic Drinks by Canadian Provincial Marketing Agencies, L6304, adopted 22 March 1988, 35S/27, 90, para. 4.26.

60 Canada made this argument in Canada-Import, Distribution and Sale of Alcoholic Drinks by Canadian Provincial Marketing Agencies, L6304, adopted 22 March 1988, 35S/27, 90, para. 4.26 (although it did not rule on the Article III claim, the Panel 'saw great force to' the opposing argument). 61 Canada - Import, Distribution and Sale of Alcoholic Drinks by Canadian Provincial Marketing Agencies, adopted 18 February 1992, BISD 39S/27, 80-82, paras. 5.17-5.22.

62 Panel Report, para. 6.43. 
noteworthy that in the past, no GATT or WTO dispute settlement report has established a violation of Article XVII. The claims of GATT-inconsistent discrimination were always decided in favour of the complainants directly on the basis of Articles I, III, and XI rather than on Article XVII' (Petersmann, 1998). ${ }^{63}$

\section{Commercial considerations and the right to regulate}

The Appellate Body's holding seems to leave significant policy space in Article XVII:1(b). Member states that use STEs to implement development policy, or industrial policy, are protected from the application of the commercial considerations requirement of Article XVII:1(b), provided that their action is not discriminatory within the meaning of Article XVII:1(a).

This was important to a number of WTO Member States. The Appellate Body noted that:

Canada, Australia, China, and the European Communities all disagree with the United States' reasoning. Essentially, they argue that accepting the United States' view of Article XVII:1(b) would force STEs to refrain from using any of the special rights or privileges that they may enjoy and, thereby, put them at a competitive disadvantage as compared to private enterprises, which can and do exercise any and all market power they can muster. These participants argue that any such interpretation would be inconsistent with the explicit recognition, in Article XVII:1, that Members are entitled to establish and maintain STEs and to grant them exclusive or special privileges. ${ }^{64}$

\section{Discrimination under Article XVII:1(a)}

Note that subparagraph (b) of Article XVII:1 deals with non-commercial considerations, which may or may not be associated with discrimination. Above, we have discussed the relationship between 'non-discrimination' under subparagraph (a) and 'commercial considerations' under subparagraph (b). This relationship depends, in part, on the meaning of 'discrimination' in Article XVII:1(a) (discussed below). On the other hand, as suggested above, while not all cases of non-commercial considerations involve discrimination, all cases of discrimination (in the WTO sense ${ }^{65}$ ) involve non-commercial considerations in the sense of subparagraph (b). After all, the WTO is concerned with discrimination because of the effects of discrimination on competition. Competition, by definition, involves the free play of the kinds of commercial considerations listed in subparagraph (b).

63 Since Petersmann wrote, a Panel in Korea-Measures Affecting Imports of Fresh, Chilled and Frozen Beef, WT/DS161,169/R, Appellate Body Report adopted 2001, found a violation of Article XVII.

64 Appellate Body Report, para. 147.

65 Excluding differential pricing, pursuant to the ad note to Article XVII:1. 
If discrimination requires differential treatment of imported and domestic products - as would seem to be suggested by 'non-discriminatory treatment prescribed in this Agreement for governmental measures affecting imports or exports by private traders' - then there will be cases in which subparagraph (a) is narrower than subparagraph (b). That is, there will be cases where the application of noncommercial considerations has no international differential or discriminatory intent or impact. We do not yet know how future Panels, and the Appellate Body, will define discrimination under Article XVII:1(a). The reference in Article $\mathrm{XVII}: 1(\mathrm{a})$ is to 'general principles of non-discriminatory treatment prescribed in this Agreement for governmental measures affecting imports or exports by private traders'.

In connection with Article III jurisprudence of de facto discrimination, a significant question arises whether national treatment is violated simply by differential treatment of like products, where likeness is determined based largely on a competitive relationship, or whether, on the other hand, national treatment is violated where regulatory categories appear to have been established with the aim of affecting the competitive position of imported products, and with that effect (see Hudec, 1998 and Porges and Trachtman, 2003). It may be that Article XVII jurisprudence will need to develop a doctrine by which to distinguish between STE measures that have been established with a similar aim and effect of discrimination, on the one hand, and STE measures that carry out a good-faith, albeit noncommercial, industrial policy.

Does the Canada-Wheat opinion require a different understanding of discrimination under Article XVII:1(a) from that which exists under Articles I, III, XIII, etc. ? To the extent that there is a difference, it would seem to be inconsistent with the express intent of Article XVII:1(a), which respects the principles of nondiscrimination reflected in those provisions. As noted above, there is some question as to which principles of non-discrimination are included.

To the extent that STEs are used for development-promotion purposes, it may be that Article XVII inhibits some of the behaviors that might be desirable. Does a distinction motivated by considerations of economic-development policy constitute discrimination in the Article XVII:1(a) sense? The Appellate Body in Canada-Wheat specifically referred to its decision in EC-Tariff Preferences, suggesting that 'discrimination' 'can accommodate both drawing distinctions per se, and drawing distinctions on an improper basis' ${ }^{66}$ While the Appellate Body was not called upon to determine which meaning prevails within Article XVII:1(a), it leaves room for a future interpretation that allows for distinctions on a proper development-policy or industrial-policy basis. Of course, STEs and similar entities that would be subject to Article XVII are just one instrument that governments may want to use to pursue development objectives. More generally, development policies may be justified under Article XVIII GATT, raising potential

66 Appellate Body Report, para. 87. 
questions concerning the consistency of any interpretations of Article XVII and Article XVIII and the Enabling Clause.

\section{What are the implications for STE-based economic policy?}

The Appellate Body decision in Canada-Wheat, declining to impose a stricter requirement on STE behavior beyond non-discrimination, leaves a great deal of regulatory freedom for states using STEs as instruments of economic policy. If the Appellate Body had accepted the US argument that Article XVII:1(b) goes beyond discrimination to impose a general requirement of commercial behavior (decision making in accordance with commercial considerations), it would have been incumbent upon the Appellate Body also to identify some limits to this requirement. For example, a different interpretative approach might have found a requirement of commercial behavior, but tempered it by a least-trade-restrictivealternative test. This would have been an act of construction, as Article XVII does not use language of this type. But it would have been practically necessary in order to allow STEs to be useful from a policy standpoint.

The Appellate Body decision does not require that STE behavior be commercial, or even efficient, but maintains the requirement that STE behavior must be nondiscriminatory - that it not impose adverse effects on other states through discrimination. The definition of discrimination may pose some difficulty, but if the focus is on aim and effects, application of Article XVII will address the intentional distortions, leaving unintentional distortions in place. This seems a reasonable balance between the right to trade and the right to regulate.

Of course, if the Appellate Body had agreed with the US that there is an independent obligation to act solely in accordance with commercial considerations, it would have introduced a procrustean requirement that STEs act as though they were not STEs. The Appellate Body would have inappropriately caused the WTO to take sides in connection with the choice between different types of organization of the economy of member states. ${ }^{67}$

Notwithstanding the resolution of this case, it is not clear that the CWB will continue to operate in its current configuration. Some Canadian farm groups are of the view that abolishing the monopoly marketing and purchasing rights of the CWB would be beneficial to them. Forces for reform include the government of Alberta, which has commissioned a study on how the monopoly might be phased out. While pressure from trading partners may have played a role in focusing attention on the efficiency and equity performance of the CWB, what is more important appears to have been perceptions that the performance of the CWB can be improved upon, and the experience of New Zealand and Australia in moving towards a private sector/cooperative model of export marketing. ${ }^{68}$

67 See Cottier and Mavroidis, 1998, warning against such intervention.

68 See Marketing Choice - The Way Forward, October 25, 2006. Available at http://www.agr.gc.ca/ cb/ip/pdf/final_251006_e.pdf. 


\section{References}

Abbott, Philip C. and Linda M. Young (2003), 'Export Competition Issues in the Doha Round', Paper presented at the International Conference: Agricultural Policy Reform and the WTO: Where Are We Heading?, 23-26 June 2003, available at http://www2.montana.edu/lmyoung/pdf-files/ Abbott\%20and\%20Young.pdf.

Alston, Julian M. and Richard S. Gray (2000), State Trading versus Export Subsidies: The Case of Canadian Wheat, Journal of Agricultural and Resource Economics, 25(1): 51-67.

Brittan, Leon (1997), 'Competition Policy and the Trading System: Toward International Rules in the WTO', Speech presented to the Institute for International Economics, Washington, DC, November 1997.

Cottier, Thomas and Petros C. Mavroidis (1998), 'Conclusions: The Reach of International Trade Law', in Thomas Cottier and Petros C. Mavroidis (eds), State Trading in the Twenty-First Century, Ann Arbor, Michigan: University of Michigan Press, pp. 395-408.

Davey, William J. (1998), 'Article XVII GATT: An Overview', in Thomas Cottier and Petros C. Mavroidis (eds), State Trading in the Twenty-First Century, Ann Arbor, Michigan: University of Michigan Press, pp. 17-36.

Dong, Fengxia, Thomas Marsh, and Kyle Stiegert (2006), 'State Trading Enterprises in a Differentiated Product Environment: The Case of Global Malting Barley Markets', American Journal of Agricultural Economics, 88(1): 90-103.

Guzman, Andrew T. (2001), 'Antitrust and International Regulatory Federalism', New York University Law Review, 76: 1142-1163.

Guzman, Andrew T. (2004), 'The Case for International Antitrust', Berkeley Journal of International Law, 22: 355-374.

Hoekman, Bernard M. and Patrick Low (1998), 'State Trading: Rule Making Alternatives for Entities with Exclusive Rights', in Thomas Cottier and Petros C. Mavroidis (eds), State Trading in the Twenty-First Century, Ann Arbor, Michigan: University of Michigan Press, pp. 327-344.

Horlick, Gary N. and Kristin Heim Mowry (1998), 'The Treatment of Activities of State Trading Enterprises under the WTO Subsidies Rules', in Thomas Cottier and Petros C. Mavroidis (eds), State Trading in the Twenty-First Century, Ann Arbor, Michigan: University of Michigan Press, pp. 97-114.

Hudec, Robert E. (1998), 'GATT/WTO Constraints on National Regulation: Requiem for an "Aim and Effects" Test', International Lawyer, 32: 619-649.

Lavoie, Nathalie (2005), 'Price Discrimination in the Context of Vertical Differentiation: An Application to Canadian Wheat Exports', American Journal of Agricultural Economics, 87(4): 835-854.

Marketing Choice - The Way Forward, 25 October 2006, available at http://www.agr.gc.ca/cb/ip/pdf/ final_251006_e.pdf.

McCorriston, Steve and Donald MacLaren (2002), 'Perspectives on the State Trading Issue in the WTO Negotiations', European Review of Agricultural Economics, 29(1): 131-154.

Paddock, Brian (1998), 'State Trading and International Trade Negotiations', Agriculture and Agri-Food Canada, December 1998, available at http://dsp-psd.communication.gc.ca/Collection/A22-1841998E.pdf.

Petersmann, Ernst-Ulrich (1998), 'GATT Law on State Trading Enterprises: Critical Evaluation of Article XVII and Proposals for Reform', in Thomas Cottier and Petros C. Mavroidis (eds), State Trading in the Twenty-First Century, Ann Arbor, Michigan: University of Michigan Press, pp. 71-96.

Porges, Amelia and Joel P. Trachtman (2003), 'Robert Hudec and Domestic Regulation: The Resurrection of "Aim and Effects", Journal of World Trade, 37(4): 783-799.

Secretariat of the World Trade Organization (1995), Operations of State Trading Enterprises as They Relate to International Trade, G/STR/2 (26 October, 1995).

Sumner, Dan and Richard Boltuck (2001), 'Anatomy of the Global Wheat Market, and the Role of the Canadian Wheat Board', Report prepared for the Canadian Wheat Board, Winnipeg. 
United States Department of Agriculture (USDA) (2002), 'US Proposal for Global Agricultural Trade Reform', Foreign Agricultural Service (FAS), Washington, DC, September 2002, available at http: //www.fas.usda.gov/itp/wto/actual.htm.

Young, Linda M. (2005), 'Export Competition Disciplines in the Doha Round', International Agricultural Trade Research Consortium, Trade Policy Issues Paper No. 3.

\section{Annex}

\section{Article XVII}

\section{State Trading Enterprises}

1.* (a) Each contracting party undertakes that if it establishes or maintains a State enterprise, wherever located, or grants to any enterprise, formally or in effect, exclusive or special privileges, ${ }^{*}$ such enterprise shall, in its purchases or sales involving either imports or exports, act in a manner consistent with the general principles of non-discriminatory treatment prescribed in this Agreement for governmental measures affecting imports or exports by private traders.

(b) The provisions of subparagraph $(a)$ of this paragraph shall be understood to require that such enterprises shall, having due regard to the other provisions of this Agreement, make any such purchases or sales solely in accordance with commercial considerations, ${ }^{*}$ including price, quality, availability, marketability, transportation and other conditions of purchase or sale, and shall afford the enterprises of the other contracting parties adequate opportunity, in accordance with customary business practice, to compete for participation in such purchases or sales.

Relevant ad notes, included in the treaty, follow:

\section{Paragraph 1}

The operations of Marketing Boards, which are established by contracting parties and are engaged in purchasing or selling, are subject to the provisions of subparagraphs $(a)$ and $(b)$.

The activities of Marketing Boards which are established by contracting parties and which do not purchase or sell but lay down regulations covering private trade are governed by the relevant Articles of this Agreement.

The charging by a state enterprise of different prices for its sales of a product in different markets is not precluded by the provisions of this Article, provided that such different prices are charged for commercial reasons, to meet conditions of supply and demand in export markets.

\section{Paragraph 1(a)}

Governmental measures imposed to insure standards of quality and efficiency in the operation of external trade, or privileges granted for the exploitation of national natural resources but which do not empower the government to exercise control over the trading activities of the enterprise in question, do not constitute 'exclusive or special privileges'. 